\title{
Effects of composite oxide supports on catalytic performance of Ni-based catalysts for $\mathrm{CO}$ methanation
}

\author{
ZHANG Han a, DONG Yunyun ${ }^{\mathrm{b}}$, FANG Weiping b,*, LIAN Yixin ${ }^{\mathrm{b}, \#}$ \\ a Department of Chemical and Biochemical Engineering, College of Chemistry and Chemical Engineering, Xiamen University, Xiamen 361005, Fujian, China \\ b Department of Chemistry, College of Chemistry and Chemical Engineering, National Engineering Laboratory for Green Chemical Productions of \\ Alcohols-Ethers-Esters, Xiamen University, Xiamen 361005, Fujian, China
}

\section{A R T I C L E I N F O}

\section{Article history:}

Received 21 September 2012

Accepted 12 November 2012

Published 20 February 2013

\section{Keywords:}

Carbon monoxide

Methanation

Nickel-based catalyst

Syngas

Mixed oxide support

\section{A B S T R A C T}

Metal-oxide-modified $\mathrm{NiO} / \mathrm{Al}_{2} \mathrm{O}_{3}$ catalysts for methanation of $\mathrm{CO}$ were prepared using a modified grinding-mixing method and characterized using X-ray diffraction, transmission electron microscopy, $\mathrm{N}_{2}$ adsorption-desorption isotherms, temperature-programmed reduction by $\mathrm{H}_{2}$, temperature-programmed desorption by $\mathrm{H}_{2}$, Raman spectroscopy, and X-ray photoelectron spectroscopy. The results show that the activity of an $\mathrm{MgO}$-modified $\mathrm{NiO} / \mathrm{Al}_{2} \mathrm{O}_{3}$ catalyst is better than those of $\mathrm{NiO} / \mathrm{ZrO}_{2}-\mathrm{Al}_{2} \mathrm{O}_{3}$ and $\mathrm{NiO} / \mathrm{SiO}_{2}-\mathrm{Al}_{2} \mathrm{O}_{3}$ in the reaction temperature range $300-700{ }^{\circ} \mathrm{C}$. The incorporation of a metal oxide into $\mathrm{NiO} / \mathrm{Al}_{2} \mathrm{O}_{3}$ was found to weaken $\mathrm{Ni}-\mathrm{Al}$ interactions, leading to generation of large numbers of active $\mathrm{Ni}$ species, and this was confirmed to be responsible for the improvement in the performances of the catalysts in the methanation reaction.

(C) 2013, Dalian Institute of Chemical Physics, Chinese Academy of Sciences. Published by Elsevier B.V. All rights reserved.

\section{Introduction}

In recent years, as oil and natural gas resources have become increasingly scarce [1-3], scientists and engineers in related fields have paid more attention to clean technologies for coal conversion. The conversion of coal to synthetic natural gas has been investigated in parallel with processes for converting coal to liquid fuels and light olefins [4]. The CO methanation reaction, the simplest Fischer-Tropsch synthesis reaction, has the advantages of a high calorific value and environmental friendliness. $\mathrm{CO}$ methanation, with methane $\left(\mathrm{CH}_{4}\right)$ as the main product, has therefore become an important alternative source of natural gas, and this reaction has been the subject of much research [5-9]. The development of efficient catalysts for CO methanation is therefore important.

There are many metallic elements which are suitable for use as catalysts for $\mathrm{CO}$ methanation, e.g., $\mathrm{Ru}$ [10], Pt [11], Co [12], and $\mathrm{Ni}$ [13]. It is well known that noble-metal catalysts, such as Ru-based catalysts, are excellent for CO methanation, but because of their high cost, large-scale commercialization and industrialization have been restricted [14]. Co-based catalysts tolerate harsh environments well, but have poor selectivity. Ni-based catalysts are superior to Co-based and Fe-based catalysts because of their high catalytic activities, high $\mathrm{CH}_{4}$ selectivities, and relatively low costs. With these advantages, Ni-based catalysts are promising as good industrial catalysts. However, conventional Ni catalysts supported on alumina are easily deactivated as a result of sintering of Ni particles and coke deposition during the exothermic methanation reaction. Also, to increase their catalytic activities, $\mathrm{Ni} / \mathrm{Al}_{2} \mathrm{O}_{3}$ catalysts usually need to have a high $\mathrm{Ni}$ content, which may cause faster deactivation of the catalyst during long-term operation $[7,15]$.

\footnotetext{
* Corresponding author. Tel./Fax: +86-592-2186291; E-mail: wpfang@xmu.edu.cn

\# Corresponding author. Tel./Fax: +86-592-2180361; E-mail: lianyx@xmu.edu.cn

This work was supported by the National Basic Research Program of China (973 Program, 2010CB226903).

DOI: 10.1016/S1872-2067(11)60485-3 | http://www.sciencedirect.com/science/journal/18722067 | Chin. J. Catal., Vol. 34, No. 2, February 2013
} 
In this work, we focused our attention on the selection of different supports for Ni-based catalysts with low $\mathrm{Ni}$ contents for syngas methanation. A series of $\mathrm{NiO} / \mathrm{MO}_{x}-\mathrm{Al}_{2} \mathrm{O}_{3}(\mathrm{M}=\mathrm{Mg}, \mathrm{Si}$, and $\mathrm{Zr}$ ) catalysts were prepared using a modified grinding-mixing method. The as-synthesized catalysts were characterized using X-ray diffraction (XRD), transmission electron microscopy (TEM), $\mathrm{N}_{2}$ adsorption-desorption isotherms, temperature-programmed reduction by $\mathrm{H}_{2}\left(\mathrm{H}_{2}\right.$-TPR), temperature-programmed desorption by $\mathrm{H}_{2}\left(\mathrm{H}_{2}\right.$-TPD), Raman spectroscopy, and X-ray photoelectron spectroscopy (XPS). The effects of $\mathrm{MO}_{x}$ on the catalytic performances of $\mathrm{NiO} / \mathrm{MO}_{x}-\mathrm{Al}_{2} \mathrm{O}_{3}$ catalysts in the methanation reaction were also investigated.

\section{Experimental}

\subsection{Catalyst preparation}

The catalysts were prepared using a modified grinding-mixing method. First, an appropriate amount of nickel nitrate hexahydrate was dissolved in nitric acid solution, followed by blending with an appropriate amount of pseudo-boehmite. After vigorously stirring for $1 \mathrm{~h}$, when an alumina gel formed, a given quantity of alumina powder was added. Then the catalyst precursor was intensively kneaded to produce a paste, extruded to $3 \mathrm{~mm} \times 3 \mathrm{~mm}$ cylinders, dried at 120 ${ }^{\circ} \mathrm{C}$ for $12 \mathrm{~h}$, and calcined in air at $500{ }^{\circ} \mathrm{C}$ for $4 \mathrm{~h} . \mathrm{MO}_{x} \mathrm{M}=\mathrm{Mg}, \mathrm{Si}$, $\mathrm{Zr}$ ) was added simultaneously with pseudo-boehmite to form $\mathrm{NiO} / \mathrm{MgO}-\mathrm{Al}_{2} \mathrm{O}_{3}, \mathrm{NiO} / \mathrm{SiO}_{2}-\mathrm{Al}_{2} \mathrm{O}_{3}$, and $\mathrm{NiO} / \mathrm{ZrO}_{2}-\mathrm{Al}_{2} \mathrm{O}_{3}$ catalysts.

\subsection{Catalytic activity tests}

The methanation reaction was carried out in a continuous-flow quartz fixed-bed reactor at $2.0 \mathrm{MPa}$ in the temperature range $300-700{ }^{\circ} \mathrm{C}$. Typically, the catalyst $(0.5 \mathrm{ml}, 20-60$ mesh) was diluted with ground quartz to prevent it from over-heating as a result of the exothermic reaction. Prior to each experiment, the catalyst was reduced in a flow of $\mathrm{H}_{2}$ for 3 $\mathrm{h}$ at $400{ }^{\circ} \mathrm{C}$ under a $5 \% \mathrm{H}_{2}$ in $\mathrm{N}_{2}$ stream. The reactor was then equilibrated to the desired reaction temperature and the reaction started when the gas flow was switched to syngas $(2.0 \%$ CO, $25.0 \% \mathrm{~N}_{2}, 73.0 \% \mathrm{H}_{2}$ ) with a gas hourly space velocity (GHSV) of $5000 \mathrm{~h}^{-1} . \mathrm{H}_{2}, \mathrm{CO}, \mathrm{CH}_{4}$, and $\mathrm{CO}_{2}$ were monitored using a GC 2060 gas chromatograph. Water in the products was separated by a cold trap before analyzing the product gases. CO conversion and selectivity for $\mathrm{CH}_{4}$ were calculated according to Eqs. (1) and (2), respectively.

$$
\begin{aligned}
\text { Conversion of } \mathrm{CO} & =\frac{\text { moles of reacted CO }}{\text { moles of supplied CO }} \times 100 \% \\
\text { Selectivity for } \mathrm{CH}_{4} & =\frac{\text { moles of } \mathrm{CH} 4 \text { formed }}{\text { moles of CO reacted }} \times 100 \%
\end{aligned}
$$

\subsection{Characterization}

Powder XRD patterns were recorded using an X'Pert Pro X-ray diffractometer (PANalytical BV, The Netherlands) at a voltage of $40 \mathrm{kV}$ and a current of $30 \mathrm{~mA}$, with $\mathrm{Cu} K_{\alpha}$ radiation. The XRD patterns were referenced to the powder diffraction files (ICDD-FDP data base) for the identification of the peaks.

TEM was performed using a Tecnai F30 high-resolution transmission electron microscope. Samples for TEM observations were suspended in ethanol and dispersed ultrasonically.

The surface textural properties were measured using a Micromeritics TriStar 3000 porosimetry analyzer at $-196^{\circ} \mathrm{C}$, using liquid $\mathrm{N}_{2}$. Before physical $\mathrm{N}_{2}$ adsorption of the samples, they were degassed under vacuum at $300{ }^{\circ} \mathrm{C}$ for $3 \mathrm{~h}$ in a separate degassing unit attached to the instrument. The specific surface area was calculated using the Brunauer-Emmett-Teller (BET) method. The pore size distribution was evaluated using the Barrett-Joyner-Halenda method.

$\mathrm{H}_{2}$-TPR was carried out in a quartz-tube fixed-bed microreactor system. The sample $(50 \mathrm{mg})$ was pretreated at $300{ }^{\circ} \mathrm{C}$ for $1 \mathrm{~h}$ under an Ar flow (30 ml/min). After cooling to $50{ }^{\circ} \mathrm{C}$, the sample was exposed to a flow (40 ml $/ \mathrm{min}$ ) of $5 \% \mathrm{H}_{2}-95 \% \mathrm{Ar}$ and ramped to $800{ }^{\circ} \mathrm{C}$ at a heating rate of $10^{\circ} \mathrm{C} / \mathrm{min}$. The effluent was monitored using a GC 950 gas chromatograph equipped with a thermal conductivity detector.

$\mathrm{H}_{2}$-TPD experiments were performed using Quantachrome equipment. The catalyst (100 $\mathrm{mg}$ ) was placed in an adsorption vessel and pretreated in $\mathrm{Ar}(50 \mathrm{ml} / \mathrm{min})$ at $300{ }^{\circ} \mathrm{C}$ for $1 \mathrm{~h}$, and then heated to $400{ }^{\circ} \mathrm{C}$ and kept at this temperature for $60 \mathrm{~min}$ in $\mathrm{H}_{2}(30 \mathrm{ml} / \mathrm{min})$. After cooling to $50{ }^{\circ} \mathrm{C}, \mathrm{H}_{2}$ was passed over the sample for $30 \mathrm{~min}$. The sample was then swept with $\mathrm{Ar}$ for $60 \mathrm{~min}$ and finally the desorption step was performed from 50 to $800{ }^{\circ} \mathrm{C}$ at a heating rate of $10^{\circ} \mathrm{C} / \mathrm{min}$ and with an $\mathrm{Ar}$ flow of $10 \mathrm{ml} / \mathrm{min}$. The desorbed products were monitored by mass spectrometry.

Raman characterization of the catalysts was carried out on a LabRam I (Jobin-Yvon) at room temperature. Spectra were recorded using the 514.5-nm excitation line of an He-Ne ion laser.

The electronic states of the fresh catalysts were determined by XPS (PHI Quantum 2000 Scanning ESCA Microprobe) using a monochromatic microfocused Al X-ray source. The binding energies were calibrated using $\mathrm{C} 1 s$ as the reference energy ( $\mathrm{C}$ $1 s=284.6 \mathrm{eV}$ ).

\section{Results and discussion}

\subsection{Catalytic performance}

Figure 1 shows the catalytic activities of the catalysts $\mathrm{NiO} / \mathrm{MO}_{x}-\mathrm{Al}_{2} \mathrm{O}_{3}$ in terms of $\mathrm{CO}$ conversion and $\mathrm{CH}_{4}$ selectivity. It can be seen from Fig. 1(a) that the $\mathrm{CO}$ conversions by the $\mathrm{NiO} / \mathrm{MO}_{x}-\mathrm{Al}_{2} \mathrm{O}_{3}$ catalysts gradually increase with increasing temperature from 300 to $700{ }^{\circ} \mathrm{C}$. The $\mathrm{NiO} / \mathrm{Al}_{2} \mathrm{O}_{3}$ catalyst shows much lower $\mathrm{CO}$ conversion than the other catalysts, indicating that incorporating $\mathrm{MgO}, \mathrm{SiO}_{2}$, or $\mathrm{ZrO}_{2}$ into the $\mathrm{NiO} / \mathrm{Al}_{2} \mathrm{O}_{3}$ catalyst significantly increases its methanation activity, especially at low temperatures. The catalytic performances of the $\mathrm{NiO} / \mathrm{MO}_{x}-\mathrm{Al}_{2} \mathrm{O}_{3}$ catalysts were different, depending on the second metal oxide $\left(\mathrm{MO}_{x}\right)$ added. The order of the catalytic activities of the $\mathrm{NiO} / \mathrm{MO}_{x}-\mathrm{Al}_{2} \mathrm{O}_{3}$ catalysts is $\mathrm{NiO} / \mathrm{MgO}-\mathrm{Al}_{2} \mathrm{O}_{3}>$ $\mathrm{NiO} / \mathrm{ZrO}_{2}-\mathrm{Al}_{2} \mathrm{O}_{3}>\mathrm{NiO} / \mathrm{SiO}_{2}-\mathrm{Al}_{2} \mathrm{O}_{3}>\mathrm{NiO} / \mathrm{Al}_{2} \mathrm{O}_{3}$. At $500{ }^{\circ} \mathrm{C}$, the $\mathrm{CO}$ conversion by $\mathrm{NiO} / \mathrm{MgO}-\mathrm{Al}_{2} \mathrm{O}_{3}$ reaches $99.6 \%$, which is 


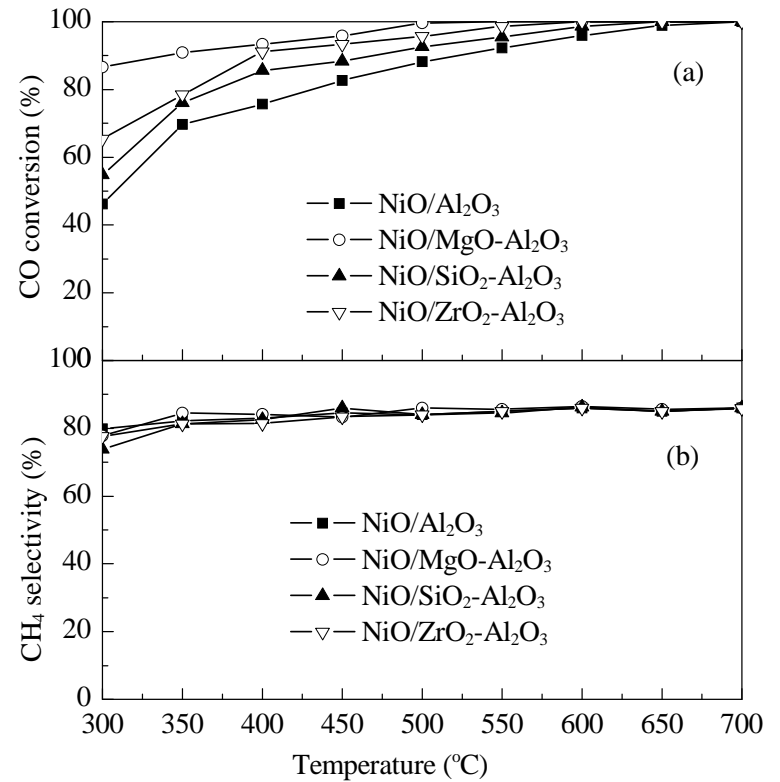

Fig. 1. $\mathrm{CO}$ conversion (a) and $\mathrm{CH}_{4}$ selectivity (b) over $\mathrm{NiO} / \mathrm{MO}_{x}-\mathrm{Al}_{2} \mathrm{O}_{3}$ catalysts as a function of reaction temperature. Reaction conditions: 2 $\mathrm{MPa}, \mathrm{GHSV}=5000 \mathrm{~h}^{-1}$.

higher than those of $\mathrm{NiO} / \mathrm{ZrO}_{2}-\mathrm{Al}_{2} \mathrm{O}_{3} \quad(95.7 \%)$ and $\mathrm{NiO} / \mathrm{SiO}_{2}-\mathrm{Al}_{2} \mathrm{O}_{3}(92.6 \%)$. It is observed from Fig. 1(b) that the $\mathrm{CH}_{4}$ selectivities of different $\mathrm{NiO} / \mathrm{MO}_{x}-\mathrm{Al}_{2} \mathrm{O}_{3}$ catalysts are similar to each other in the temperature range $350-700{ }^{\circ} \mathrm{C}$, and are as high as $80 \%$.

\subsection{Catalyst characterization}

\subsubsection{XRD and TEM analysis of Ni-based catalysts}

The XRD patterns of $\mathrm{Al}_{2} \mathrm{O}_{3}$ and the Ni-based catalysts supported on $\mathrm{Al}_{2} \mathrm{O}_{3}$ reduced at $400{ }^{\circ} \mathrm{C}$ are displayed in Fig. 2. For $\mathrm{Al}_{2} \mathrm{O}_{3}$, the three broad diffraction peaks of $\gamma-\mathrm{Al}_{2} \mathrm{O}_{3}$ are clearly present. No other diffraction peaks arising from the $\mathrm{NiO} / \mathrm{Al}_{2} \mathrm{O}_{3}$, $\mathrm{NiO} / \mathrm{MgO}-\mathrm{Al}_{2} \mathrm{O}_{3}$, and $\mathrm{NiO} / \mathrm{SiO}_{2}-\mathrm{Al}_{2} \mathrm{O}_{3}$ catalysts are seen, i.e., no clear characteristic diffraction peaks corresponding to free $\mathrm{Ni}$ species are detected [16], indicating that NiO is highly dispersed on the surface of the catalysts and small grains that are below the detection limit of XRD measurements are formed $[17,18]$.

To examine the dispersion and morphologies of $\mathrm{Ni}$ on the supports, TEM analysis was performed on a series of supported catalysts. The TEM images in Fig. 3 all show that the NiO particles are uniformly dispersed on the supports. This is in agreement with the XRD results. One possible reason is the relatively

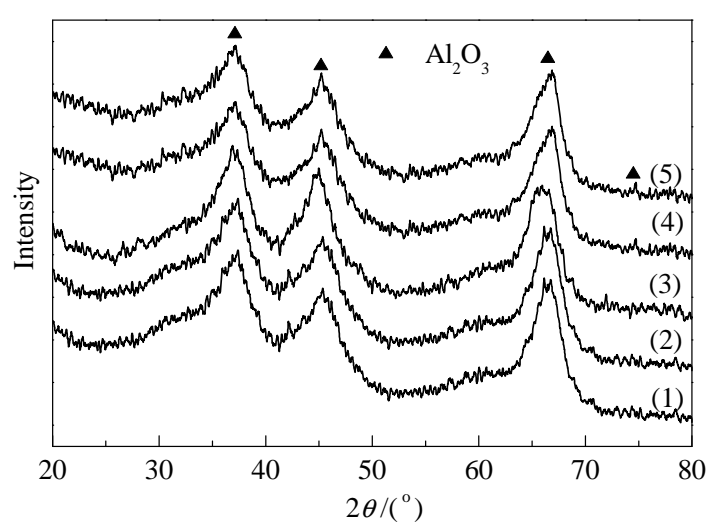

Fig. 2. XRD patterns of reduced Ni-based catalysts and $\mathrm{Al}_{2} \mathrm{O}_{3}$. (1) $\mathrm{Al}_{2} \mathrm{O}_{3}$; (2) $\mathrm{NiO} / \mathrm{Al}_{2} \mathrm{O}_{3}$; (3) $\mathrm{NiO} / \mathrm{MgO}-\mathrm{Al}_{2} \mathrm{O}_{3}$; (4) $\mathrm{NiO} / \mathrm{SiO}_{2}-\mathrm{Al}_{2} \mathrm{O}_{3}$; (5) $\mathrm{NiO} / \mathrm{ZrO}_{2}$ $\mathrm{Al}_{2} \mathrm{O}_{3}$.

low Ni loadings. The differences among these catalysts could not be seen from the XRD and TEM analyses, so other characterization methods were used.

\subsection{2. $\mathrm{N}_{2}$ adsorption-desorption isotherms}

The $\mathrm{N}_{2}$ adsorption-desorption isotherms of different $\mathrm{NiO} / \mathrm{MO}_{x}-\mathrm{Al}_{2} \mathrm{O}_{3}$ catalysts are shown in Fig. 4. Clearly, all the isotherms are type IV, which is characteristic of a mesoporous structure with a hysteresis loop. This type of loop is usually ascribed to ink-bottle pores, with narrow orifices and broader inner parts [19]. The BET surface areas, average pore sizes, and pore volumes of the $\mathrm{NiO} / \mathrm{MO}_{x}-\mathrm{Al}_{2} \mathrm{O}_{3}$ catalysts are summarized in Table 1 . The specific surface area of $\mathrm{NiO} / \mathrm{Al}_{2} \mathrm{O}_{3}$ is $192 \mathrm{~m}^{2} / \mathrm{g}$. It decreased to $159 \mathrm{~m}^{2} / \mathrm{g}$ after the addition of $\mathrm{MgO}$. Generally, the higher the surface area is, the higher the catalytic performance is, but this is not consistent with our observations. The work of Guo et al. [20] and the evaluation results for our catalysts show that the catalyst area is not directly related to the catalytic activity for CO methanation in this system. It is the chemical properties, rather than the physical properties, that mainly determine the catalyst performance.

\subsection{3. $\mathrm{H}_{2}$-TPD characterization}

Figure 5 shows the $\mathrm{H}_{2}$-TPD profiles of the reduced $\mathrm{NiO} / \mathrm{MO}_{x}-\mathrm{Al}_{2} \mathrm{O}_{3}$ catalysts. All the profiles show a very small hydrogen desorption peak in the temperature range 150-350 ${ }^{\circ} \mathrm{C}$ and a broad hydrogen desorption peak in the temperature range $400-700{ }^{\circ} \mathrm{C}$, which can be ascribed to dominant hydrogen adsorption at active sites on the $\mathrm{Ni}$ grain surfaces. The intensities of the $\mathrm{Ni}-\mathrm{Al}$ interactions in these four catalysts are

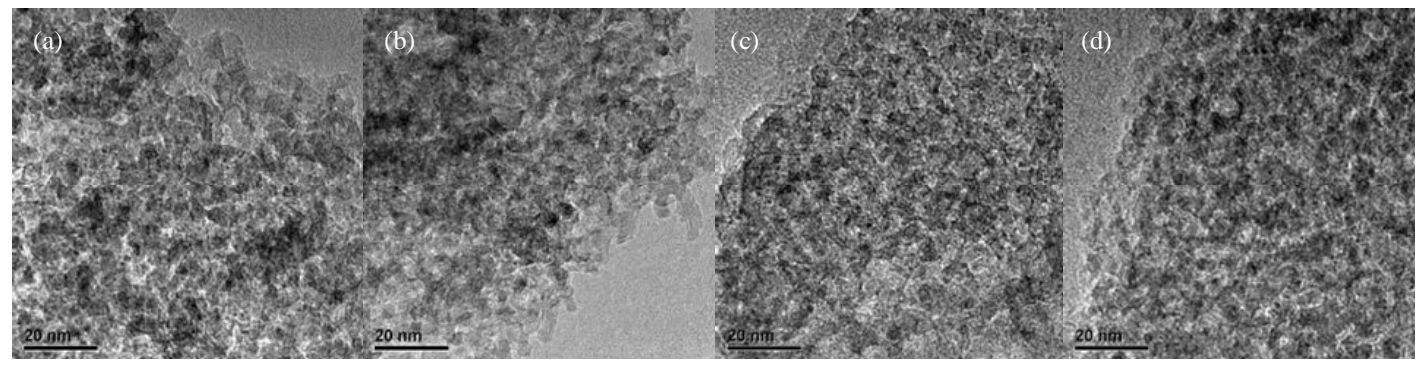

Fig. 3. TEM images of different $\mathrm{NiO} / \mathrm{MO}_{x}-\mathrm{Al}_{2} \mathrm{O}_{3}$ catalysts. (a) $\mathrm{NiO} / \mathrm{Al}_{2} \mathrm{O}_{3}$; (b) $\mathrm{NiO} / \mathrm{MgO}-\mathrm{Al}_{2} \mathrm{O}_{3}$; (c) $\mathrm{NiO} / \mathrm{SiO}_{2}-\mathrm{Al}_{2} \mathrm{O}_{3} ;$ (d) $\mathrm{NiO} / \mathrm{ZrO}_{2}-\mathrm{Al}_{2} \mathrm{O}_{3}$. 


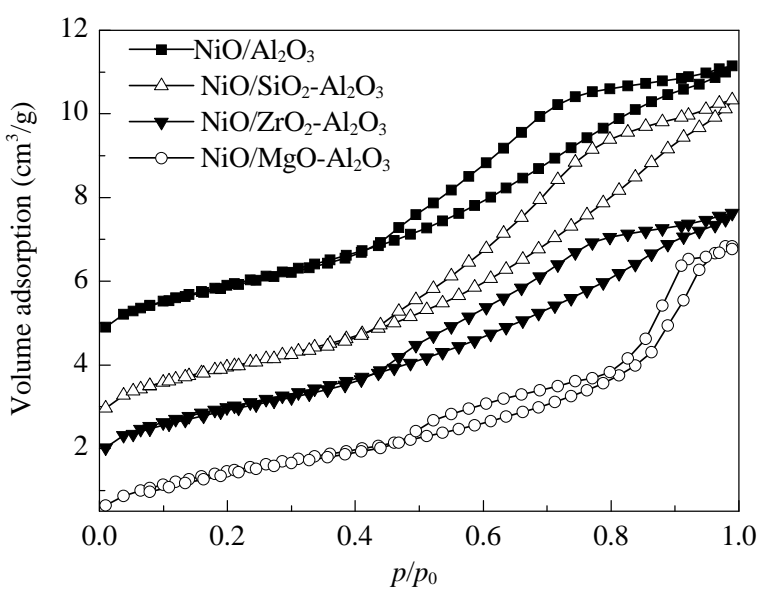

Fig. 4. $\mathrm{N}_{2}$ adsorption-desorption isotherms of $\mathrm{NiO} / \mathrm{MO}_{x}-\mathrm{Al}_{2} \mathrm{O}_{3}$ catalysts calcined at $500^{\circ} \mathrm{C}$.

Table 1

Surface areas, pore volumes, and average pore diameters of fresh $\mathrm{NiO} /$ $\mathrm{MO}_{x}-\mathrm{Al}_{2} \mathrm{O}_{3}$ catalysts.

\begin{tabular}{lccc}
\hline Catalyst & $\begin{array}{c}\text { BET surface area } \\
\left(\mathrm{m}^{2} / \mathrm{g}\right)\end{array}$ & $\begin{array}{c}\text { Pore volume } \\
\left(\mathrm{cm}^{3} / \mathrm{g}\right)\end{array}$ & $\begin{array}{c}\text { Pore diameter } \\
(\mathrm{nm})\end{array}$ \\
\hline $\mathrm{NiO} / \mathrm{Al}_{2} \mathrm{O}_{3}$ & 192 & 0.26 & 4.6 \\
$\mathrm{NiO} / \mathrm{MgO}_{-} \mathrm{Al}_{2} \mathrm{O}_{3}$ & 159 & 0.25 & 6.0 \\
$\mathrm{NiO} / \mathrm{SiO}_{2}-\mathrm{Al}_{2} \mathrm{O}_{3}$ & 193 & 0.30 & 5.4 \\
$\mathrm{NiO} / \mathrm{ZrO}_{2}-\mathrm{Al}_{2} \mathrm{O}_{3}$ & 186 & 0.24 & 4.6 \\
\hline
\end{tabular}

different, but they are generally high, and the Ni loadings are low. All these factors lead to the small hydrogen desorption peak in the low-temperature range. Among the catalysts tested, $\mathrm{NiO} / \mathrm{MgO}-\mathrm{Al}_{2} \mathrm{O}_{3}$ exhibits the highest peak intensity. This can be attributed to larger amounts of active Ni species. The amount of desorbed hydrogen, corresponding to the peak area, depends on the second metal oxide added and increases in the order $\mathrm{NiO} / \mathrm{Al}_{2} \mathrm{O}_{3}<\mathrm{NiO} / \mathrm{SiO}_{2}-\mathrm{Al}_{2} \mathrm{O}_{3}<\mathrm{NiO} / \mathrm{ZrO}_{2}-\mathrm{Al}_{2} \mathrm{O}_{3}<\mathrm{NiO} / \mathrm{MgO}-$ $\mathrm{Al}_{2} \mathrm{O}_{3}$. The area of the $\mathrm{H}_{2}$-TPD peak correlates well with the amount of active Ni species. The larger the peak area and the larger the amount of hydrogen adsorbed, the higher the catalytic activity [21]. From the mechanism of CO methanation $[22,23]$, we know that the amount of hydrogen involved in the methanation reaction is one of the crucial factors determining

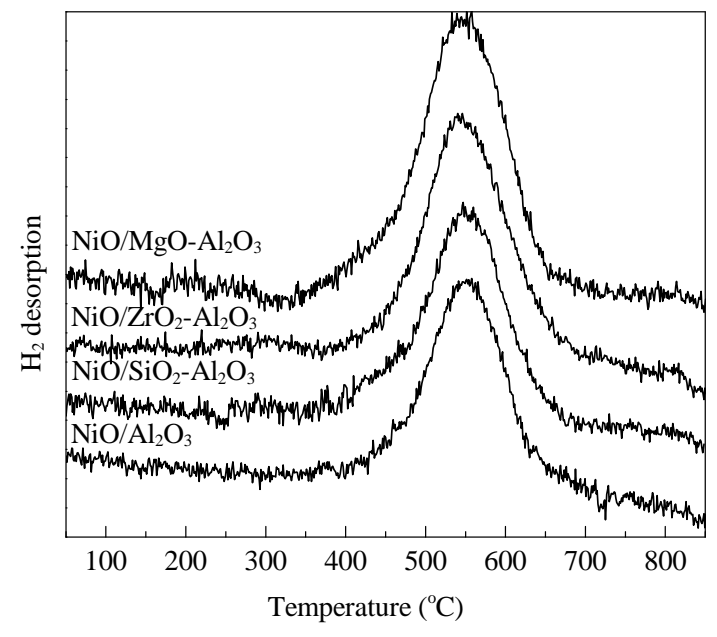

Fig. 5. $\mathrm{H}_{2}$-TPD profiles of the reduced $\mathrm{NiO} / \mathrm{MO}_{x}-\mathrm{Al}_{2} \mathrm{O}_{3}$ catalysts. catalytic performance. In a hydrogen atmosphere, surface carbon and oxygen species formed through CO dissociation are speedily converted to $\mathrm{CH}_{4}$ and $\mathrm{CO}_{2}$ and desquamate from the surface to provide adsorption centers for further CO adsorption, thereby accelerating $\mathrm{CO}$ adsorption $[24,25]$. An increase in hydrogen adsorption could therefore enhance $\mathrm{CO}$ adsorption on the catalyst surface, promoting activation of hydrogen and CO [26]. As a result, the catalyst performance will be improved.

\subsection{4. $\mathrm{H}_{2}$-TPR characterization}

$\mathrm{H}_{2}$-TPR characterization was conducted to understand the reducibilities and the optimum reduction temperatures for the Ni-based catalysts. All the $\mathrm{H}_{2}$-TPR experiments ended at a temperature of $800{ }^{\circ} \mathrm{C}$, as shown in Fig. 6. Two reduction peaks were observed in the $\mathrm{H}_{2}$-TPR profiles. The reduction peaks that appeared in the temperature range $300-450{ }^{\circ} \mathrm{C}$, with an optimum temperature at around $400{ }^{\circ} \mathrm{C}$, can be ascribed partly to $\mathrm{NiO}$ and partly to $\mathrm{Ni}^{2+}$ species weakly interacting with the support. The reduction peaks observed in the temperature range $500-800{ }^{\circ} \mathrm{C}$, with an optimum temperature at around $700{ }^{\circ} \mathrm{C}$, probably correspond to the reduction of $\mathrm{Ni}^{2+}$ in the $\mathrm{NiAl}_{2} \mathrm{O}_{4}$ phase [6,27-29] or to Ni interacting strongly with the support. This $\mathrm{NiAl}_{2} \mathrm{O}_{4}$ spinel phase has a stable structure and is difficult to reduce to $\mathrm{Ni}^{0}$ species at low temperatures. In general, the changes in the optimum reduction temperature reflect the extent of interactions between the active component and the support. The temperature at which the first reduction peak appeared shifted downwards from 402 to $378{ }^{\circ} \mathrm{C}$, suggesting that the reduction of $\mathrm{NiO}$ to $\mathrm{Ni}^{0}$ becomes easier after $\mathrm{Mg}$, $\mathrm{Si}$, or $\mathrm{Zr}$ addition, and the active $\mathrm{Ni}$ component in the $\mathrm{NiO} / \mathrm{Al}_{2} \mathrm{O}_{3}$ catalyst has stronger interactions with the support and is more difficult to reduce compared with the other $\mathrm{NiO} / \mathrm{MO}_{x}-\mathrm{Al}_{2} \mathrm{O}_{3}$ catalysts.

The catalyst reduction ability is directly related to the amount of free nickel-oxide species. For $\mathrm{NiO} / \mathrm{Al}_{2} \mathrm{O}_{3}$, there may be only a few free nickel-oxide species in the catalyst. However, $\mathrm{NiO} / \mathrm{MgO}-\mathrm{Al}_{2} \mathrm{O}_{3}$ has many free nickel-oxide species, and these make reduction of the catalyst easier at low temperatures. As can be seen from Fig. 5, the intensities of the peaks arising from $\mathrm{NiO}$ in $\mathrm{NiO} / \mathrm{MO}_{x}-\mathrm{Al}_{2} \mathrm{O}_{3}$ are in the order $\mathrm{NiO} / \mathrm{MgO}-\mathrm{Al}_{2} \mathrm{O}_{3}>$

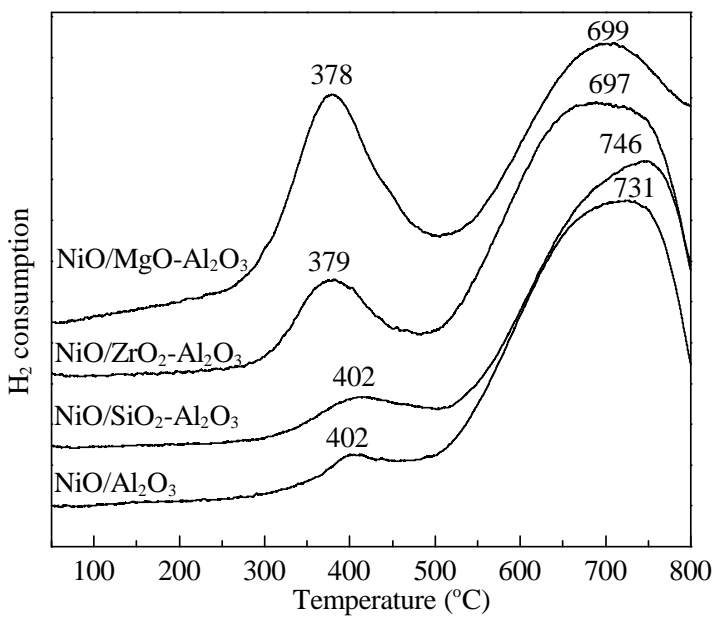

Fig. 6. $\mathrm{H}_{2}$-TPR profiles of the $\mathrm{NiO} / \mathrm{MO}_{x}-\mathrm{Al}_{2} \mathrm{O}_{3}$ catalysts. 


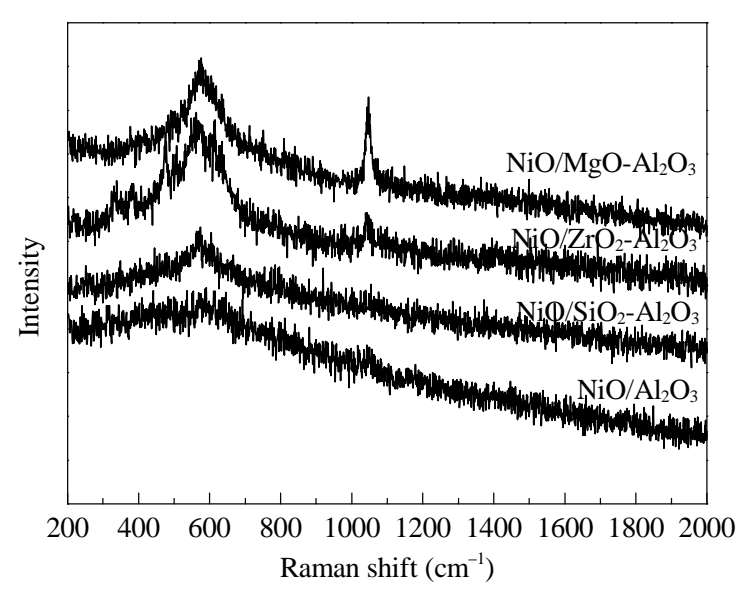

Fig. 7. Raman spectra of the $\mathrm{NiO} / \mathrm{MO}_{x}-\mathrm{Al}_{2} \mathrm{O}_{3}$ catalysts.

$\mathrm{NiO} / \mathrm{ZrO}_{2}-\mathrm{Al}_{2} \mathrm{O}_{3}>\mathrm{NiO} / \mathrm{SiO}_{2}-\mathrm{Al}_{2} \mathrm{O}_{3}>\mathrm{NiO} / \mathrm{Al}_{2} \mathrm{O}_{3}$. This is in good agreement with those obtained from Raman characterization (Fig. 7).

\subsubsection{Raman spectra}

Figure 7 shows the Raman spectra for the $\mathrm{NiO} / \mathrm{MO}_{x}-\mathrm{Al}_{2} \mathrm{O}_{3}$ catalysts. It is well known that the only phase of alumina that exhibits Raman bands is $\alpha-\mathrm{Al}_{2} \mathrm{O}_{3}$ [22]. In our present work, the catalysts were calcined at $500{ }^{\circ} \mathrm{C}$, and only the $\gamma-\mathrm{Al}_{2} \mathrm{O}_{3}$ phase was formed, from which no Raman bands would be observed $[22,23]$. For the $\mathrm{NiO} / \mathrm{MO}_{x}-\mathrm{Al}_{2} \mathrm{O}_{3}$ catalysts, there are two explicit Raman peaks, at around 546 and $1092 \mathrm{~cm}^{-1}$, as shown in Fig. 7. Based on previous results $[21,30]$, these two peaks are the characteristic bands of the first-order longitudinal optical (LO) phonon modes of cubic NiO single-crystals and a combination of 2LO modes, respectively. The amounts of active free Ni species on the surfaces of the catalysts could therefore be estimated by comparing the intensities of these two NiO Raman peaks [31]. The peak intensity specific to free nickel-oxide species in $\mathrm{NiO} / \mathrm{MgO}-\mathrm{Al}_{2} \mathrm{O}_{3}$ is the strongest. Only a weak $\mathrm{NiO}$ signal peak was observed for $\mathrm{NiO} / \mathrm{Al}_{2} \mathrm{O}_{3}$, suggesting that there is little $\mathrm{NiO}$ on the surface of this catalyst. One reason is that large amounts of $\mathrm{NiO}$ species could enter into the support during preparation and pretreatment [32]. It is therefore reasonable to conclude

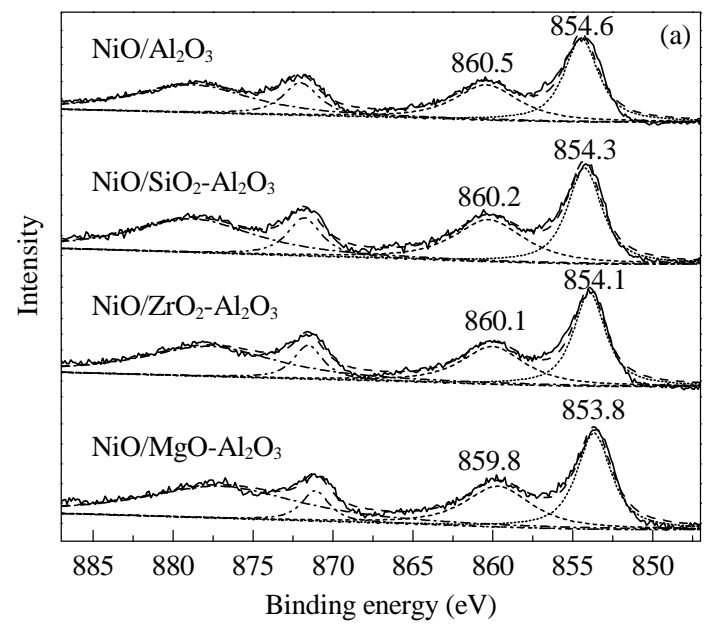

that addition of a metal oxide to $\mathrm{NiO} / \mathrm{Al}_{2} \mathrm{O}_{3}$ will favor formation of active free $\mathrm{Ni}$ species.

\subsubsection{XPS analysis}

XPS spectra specific to $\mathrm{Ni} 2 p_{3 / 2}$ and $\mathrm{Al} 2 p$ of the catalysts are presented in Fig. 8. Figure 8(a) shows the existence of two types of $\mathrm{Ni}$ species, corresponding to the main peaks at around 854 and $860 \mathrm{eV}$. From the $\mathrm{H}_{2}$-TPR results, it can be inferred that there might be $\mathrm{NiO}$ and $\mathrm{NiAl}_{2} \mathrm{O}_{4}$ on the catalyst surfaces [27]. The former is characterized by weak interactions with the support [33]. The latter may be $\mathrm{NiAl}_{2} \mathrm{O}_{4}$ or $\mathrm{Ni}^{2+}$, which are characterized by strong interactions with the support. It has been noted that the binding energy of the $\mathrm{Ni} 2 \mathrm{p}_{3 / 2}$ peak arising from $\mathrm{NiO} / \mathrm{Al}_{2} \mathrm{O}_{3}$ was higher than that for the others, as a result of stronger interactions between $\mathrm{Ni}$ and the support. However, the binding energy of $\mathrm{Ni}$ in the $\mathrm{NiO} / \mathrm{MgO}-\mathrm{Al}_{2} \mathrm{O}_{3}$ catalyst shifted down by the largest extent, followed by $\mathrm{NiO} / \mathrm{ZrO}_{2}-\mathrm{Al}_{2} \mathrm{O}_{3}$ and $\mathrm{NiO} / \mathrm{SiO}_{2}-\mathrm{Al}_{2} \mathrm{O}_{3}$. This implies that when another metal oxide is added to the $\mathrm{NiO} / \mathrm{Al}_{2} \mathrm{O}_{3}$ catalyst, the interactions between the active component, i.e., $\mathrm{NiO}$, and the support will be weakened. This speculation is in line with the XPS spectra specific to $\mathrm{Al} 2 p$ (Fig. 8(b)). As can be seen from the curves, the binding energy of the $\mathrm{Al} 2 p$ peak for $\mathrm{NiO} / \mathrm{Al}_{2} \mathrm{O}_{3}$ is at $74 \mathrm{eV}$, which is typical of $\mathrm{Al}^{3+}$ in the spinel phase [34], but for $\mathrm{NiO} / \mathrm{MgO}-\mathrm{Al}_{2} \mathrm{O}_{3}$, the binding energy is smaller.

\section{Conclusions}

$\mathrm{NiO} / \mathrm{Al}_{2} \mathrm{O}_{3}$ catalysts for $\mathrm{CO}$ methanation can be promoted by the addition of metal oxides, namely $\mathrm{MgO}, \mathrm{SiO}_{2}$, and $\mathrm{ZrO}_{2}$. $\mathrm{MgO}$ was found to be the most efficient promoter, giving a $\mathrm{CO}$ conversion as high as $99.6 \%$ at $500{ }^{\circ} \mathrm{C}$. In the $\mathrm{NiO} / \mathrm{MgO}-\mathrm{Al}_{2} \mathrm{O}_{3}$ catalyst, the $\mathrm{Ni}-\mathrm{Al}$ interactions are significantly weakened and consequently reduction of the catalyst at low temperatures is easy, leading to generation of more free nickel-oxide species on the catalyst surface.

\section{References}

[1] Kopyscinski J, Schildhauer T J, Biollaz S M. Fuel, 2010, 89: 1763

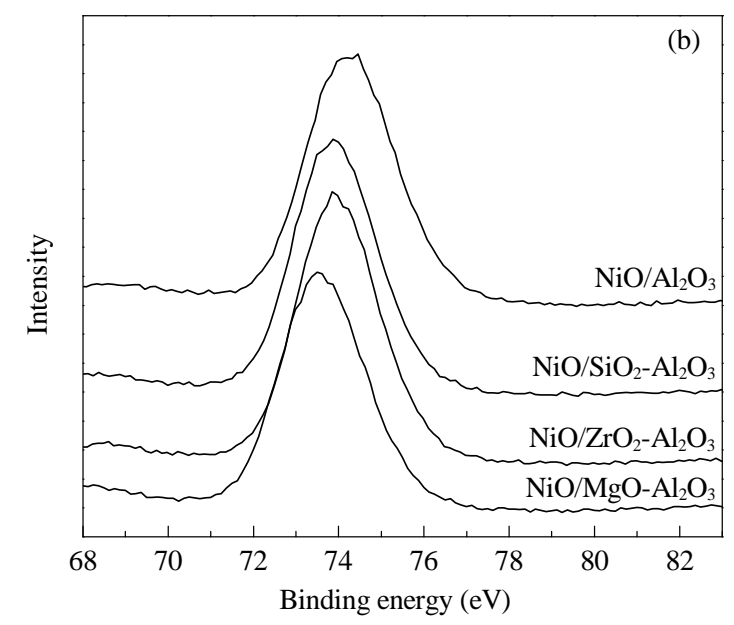

Fig. 8. $\mathrm{Ni} 2 p_{3 / 2}$ (a) and $\mathrm{Al} 2 p$ (b) XPS spectra of $\mathrm{NiO} / \mathrm{MO}_{x}-\mathrm{Al}_{2} \mathrm{O}_{3}$. 


\section{Graphical Abstract}

Chin. J. Catal., 2013, 34: 330-335 doi: 10.1016/S1872-2067(11)60485-3

\section{Effects of composite oxide supports on catalytic performance of Ni-based catalysts} for CO methanation

ZHANG Han, DONG Yunyun, FANG Weiping*, LIAN Yixin*

Xiamen University

$\mathrm{NiO} / \mathrm{MO}_{x}-\mathrm{Al}_{2} \mathrm{O}_{3}(\mathrm{M}=\mathrm{Mg}, \mathrm{Si}, \mathrm{Zr})$ catalysts for $\mathrm{CO}$ methanation, prepared using a modified grinding-mixing method, have higher catalytic activities than that of a conventional $\mathrm{NiO} / \mathrm{Al}_{2} \mathrm{O}_{3}$ catalyst. This is attributed to the weakening of $\mathrm{Ni}-\mathrm{Al}$ interactions after adding $\mathrm{MO}_{x}$.

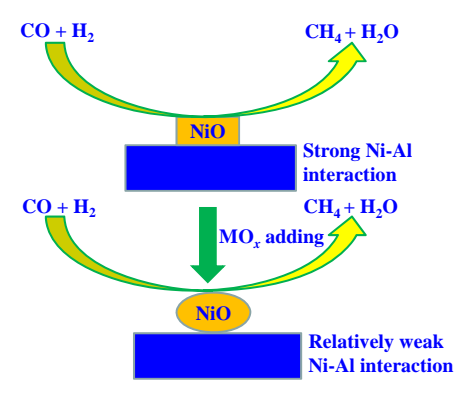

[2] Wu R F, Wang Y Z, Gao C G, Zhao Y X. J Fuel Chem Technol, 2009, 37: 578

[3] Turner J A. Science, 2004, 305: 972

[4] Huffman G P. Fuel, 2011, 90: 2671

[5] Zhao A, Ying W, Zhang H, Ma H, Fang D. Catal Commun, 2012, 17: 34

[6] Liu Z, Chu B, Zhai X, Jin Y, Cheng Y. Fuel, 2012, 95: 599

[7] Wang S H, Lee J, Hong U G, Jung J C, Koh D J, Lim H, Byun C, Song I K. J Ind Eng Chem, 2002, 18: 243

[8] Takenaka S, Shimizu T, Otsuka K. Int J Hydrogen Energy, 2004, 29: 1065

[9] Urasaki K, Endo K I, Takahiro T, Kikuchi R, Kojima T, Satokawa S. Top Catal, 2010, 53: 707

[10] Galletti C, Specchia S, Specchia V. Chem Eng J, 2011, 167: 616

[11] Bajusz J G, Kwik D J, Goodwin J G. Catal Lett, 1997, 48: 151

[12] Kok E, Scott J, Cant N, Trimm D. Catal Today, 2011, 164: 297

[13] Kim S H, Nam S W, Lim T H, Lee H I. Appl Catal B, 2008, 81: 97

[14] Duan X, Qian G, Zhou X, Sui Z, Chen D, Yuan W. Appl Catal B, 2011, 101: 189

[15] Kelley R D, Candela G A, Madey T E, Newbury D E, Schehl R R. J Catal, 1983, 80: 235

[16] Song H L, Yang J, Zhao J, Chou L J. Chin J Catal (宋焕玲, 杨建, 赵军, 丑凌军. 催化学报), 2010, 31: 21

[17] Zhao A M, Ying W Z, Zhang H T, Ma H F, Fang D Y. J Nat Gas Chem, 2012, 21: 170

[18] Ma S L, Tan Y S, Han Y Z.J Nat Gas Chem, 2011, 20: 435
[19] Wang J, Wang Y, Wen J, Shen M, Wang W. Microporous Mesoporous Mater, 2009, 121: 208

[20] Guo J, Lou H, Zhao H, Chai D, Zheng X. Appl Catal A, 2004, 273: 75

[21] Dietz R E, Parisot G I, Meixner A E. Phys Rev B, 1971, 4: 2302

[22] Aminzadeh A, Sarikhani-Fard H. Spectrochim Acta Part A, 1999, 55A: 1421

[23] Mortensen A, Christensen D H, Nielsen O F, Pedersen E. J Raman Spectrosc, 1991, 22: 47

[24] Alstrup I. J Catal, 1995, 151: 216

[25] Yadav R, Rinker R G. Ind Eng Chem Res, 1992, 31: 502

[26] Dai X P, Yu C C. J Nat Gas Chem, 2008, 17: 365

[27] Cai M D, Wen J, Chu W, Cheng X Q, Li Z J. J Nat Gas Chem, 2011, 20: 318

[28] Seo J G, Youn M H, Song I K. J Mol Catal A, 2007, 268: 9

[29] Yang J, Wang X, Li L, Shen K, Lu X, Ding W. Appl Catal B, 2010, 96: 232

[30] Wang W Z, Liu Y K, Xu C K, Zheng C L, Wang G H. Chem Phys Lett, 2002, 362: 119

[31] Liu S L, Xiong G X, Yang W S, Xu L Y, Xiong G, Li C. Catal Lett, 1999, 63: 167

[32] Maluf S S, Assaf E M. Fuel, 2009, 88: 1547

[33] Guimon C, Auroux A, Romero E, Monzon A. Appl Catal A, 2003, 251: 199

[34] Ashok J, Raju G, Reddy P S, Subrahmanyam M, Venugopal A. Int J Hydrogen Energy, 2008, 33: 4809

\section{复合氧化物载体对镍基催化剂上 CO 甲烷化反应性能的影响 \\ 张 军 ${ }^{\mathrm{a}}$, 董云芸 ${ }^{\mathrm{b}}$, 方维平 ${ }^{\mathrm{b},}$, 连奕新 ${ }^{\mathrm{b}, \#}$ \\ $\mathrm{a}$ 厦门大学化学化工学院化学工程与生物工程系, 福建厦门 361005 \\ b厦门大学化学化工学院化学系, 醇梄酯化工清洁生产国家工程实验室, 福建厦门 361005}

摘要: 采用改良的粉末混合法制备了系列经过其它金属氧化物改性的 $\mathrm{NiO} / \mathrm{Al}_{2} \mathrm{O}_{3}$ 催化剂, 并运用 X 射线衍射、透射电子显微镜、 $\mathrm{N}_{2}$ 低温物理吸附-脱附、程序升温还原、程序升温脱附、拉曼以及 $\mathrm{X}$ 射线光电子能谱对催化剂进行了表征. 结果显示, 在 $300 \sim 700^{\circ} \mathrm{C}$ 经 $\mathrm{MgO}$ 修饰的 $\mathrm{NiO} / \mathrm{Al}_{2} \mathrm{O}_{3}$ 催化剂上 $\mathrm{CO}$ 甲烷化反应活性比 $\mathrm{NiO} / \mathrm{ZrO}_{2}-\mathrm{Al}_{2} \mathrm{O}_{3}$ 和 $\mathrm{NiO} / \mathrm{SiO}_{2}-\mathrm{Al}_{2} \mathrm{O}_{3}$ 的高. 另一金属氧化物的加入削弱了 $\mathrm{NiO} / \mathrm{Al}_{2} \mathrm{O}_{3}$ 催化剂中 $\mathrm{Ni}-\mathrm{Al}$ 间相互作用,形成更多的活性 $\mathrm{Ni}$ 物种, 从而促进了反应的进行.

关键词: 一氧化碳; 甲烷化; 镍基催化剂; 合成气; 复合氧化物载体

收稿日期: 2012-09-21. 接受日期: 2012-11-12. 出版日期: 2013-02-20.

*通讯联系人. 电话/传真: (0592)2186291; 电子信箱: wpfang@xmu.edu.cn

\#通讯联系人. 电话/传真: (0592)2180361; 电子信箱: lianyx@xmu.edu.cn

基金来源: 国家重点基础研究发展计划 (973 计划, 2010CB226903).

本文的英文电子版由Elsevier出版社在ScienceDirect上出版(http://www.sciencedirect.com/science/journal/18722067). 